Provided for non-commercial research and education use. Not for reproduction, distribution or commercial use.

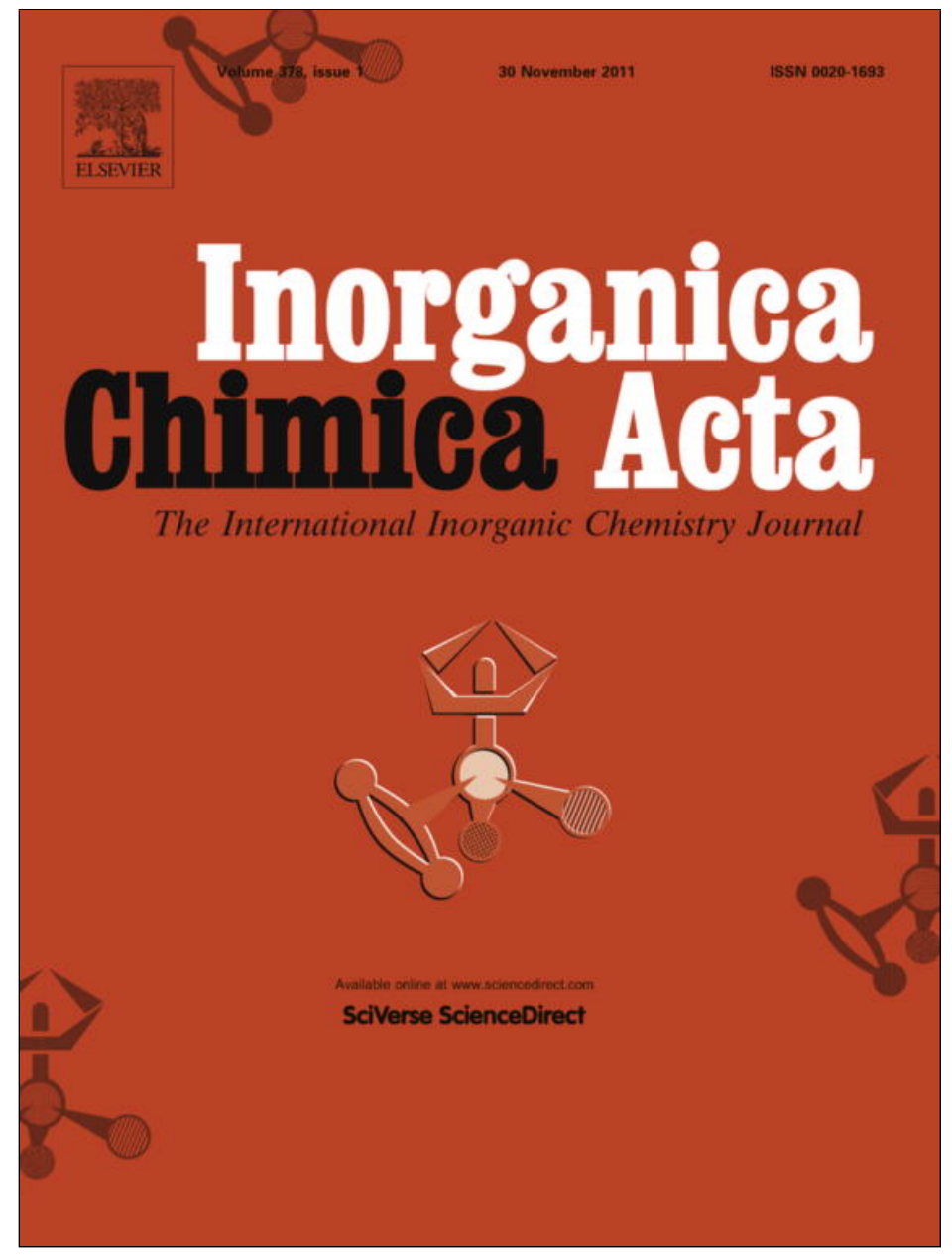

This article appeared in a journal published by Elsevier. The attached copy is furnished to the author for internal non-commercial research and education use, including for instruction at the authors institution and sharing with colleagues.

Other uses, including reproduction and distribution, or selling or licensing copies, or posting to personal, institutional or third party websites are prohibited.

In most cases authors are permitted to post their version of the article (e.g. in Word or Tex form) to their personal website or institutional repository. Authors requiring further information regarding Elsevier's archiving and manuscript policies are encouraged to visit:

http://www.elsevier.com/copyright 


\title{
5f-Element complexes with a p-tert-butylcalix[4]arene bearing phosphinoyl pendant arms: Separation from rare earths and structural studies
}

\author{
Flor de María Ramírez ${ }^{\mathrm{a}, *}$, Sabi Varbanov ${ }^{\text {b }}$, Jean-Claude G. Bünzli ${ }^{\text {c,* }}$, Rosario Scopelliti ${ }^{\mathrm{c}}$ \\ a Instituto Nacional de Investigaciones Nucleares, Departamento de Química, Carretera México-Toluca S/N, La Marquesa, Ocoyoacac C.P. 52750, Mexico \\ ${ }^{\mathrm{b}}$ Institute of Organic Chemistry with Center of Phytochemistry, Bulgarian Academy of Sciences, BG-1113 Sofia, Bulgaria \\ ' École polytechnique Fédérale de Lausanne (EPFL), Institute of Chemical Sciences and Engineering, BCH 1402, CH-1015 Lausanne, Switzerland
}

\section{A R T I C L E I N F O}

\section{Article history:}

Received 22 June 2011

Accepted 25 August 2011

Available online 9 September 2011

\section{Keywords:}

Thorium calixarene complexes

Rare earths

X-ray crystal structure of lanthanum

calixarene complex

Extraction

Separation

Molecular modeling

\begin{abstract}
A B S T R A C T
Phosphinoylated calixarenes feature high coordination ability toward $f$ elements and a great potentiality toward actinide/rare earth separation. Here, we report three characteristic properties of a tetra-phosphinoylated $p$-tert-butylcalix[4] arene, $\mathrm{B}_{4} \mathrm{bL}^{4}$ functionalized with phosphinoyl pendant arms: (i) its coordination ability toward Th(IV) complexation in organic medium, (ii) its ability to separate thorium from yttrium, lanthanum, and europium in three different organic media, and (iii) the $\mathrm{X}$-ray crystal structure of the La complex. Thorium(IV) forms $1: 1$ and $1: 2$ (M:L) complexes with $\mathrm{B}_{4} \mathrm{bL}^{4}: \mathrm{Th}\left(\mathrm{NO}_{3}\right)_{4}\left(\mathrm{~B}_{4} \mathrm{bL}^{4}\right)_{n} \cdot x \mathrm{H}_{2} \mathrm{O}$ $(n=1, x=1,1 ; n=2, x=4,2)$. Spectroscopic data point to the inner coordination sphere of 1 and 2 containing nitrate ions and water molecules. Molecular modeling of $\mathbf{1}$ yielded an 8-coordinate species and its coordination polyhedron can be described as a distorted square antiprism while that for $\mathbf{2}$, a 9-coordinate species, as a distorted tricapped trigonal prism. The extraction study of tetravalent thorium and trivalent rare-earth (Y, La, Eu) ions from acidic nitrate media by $\mathrm{B}_{4} \mathrm{bL}^{4}$ in chloroform shows thorium being much more extracted than the rare earths, with selectivity close to $100 \%$. The extraction behavior can be easily modulated by changing the initial conditions $(\mathrm{pH}$, nitrate concentration). The X-ray structure of $\left[\mathrm{LaB}_{4} \mathrm{bL}^{4}\left(\mathrm{H}_{2} \mathrm{O}\right)_{5}\right] \mathrm{CH}_{3} \mathrm{CN} \cdot\left(\mathrm{ClO}_{4}\right)_{3}$ points to the La ${ }^{\text {III }}$ ion lying on a $\mathrm{C}_{4}$ axis and being 9-coordinated by the four $\mathrm{O}(\mathrm{P})$ atoms and five $\mathrm{O}$ atoms from water molecules. It is located in the middle of the void formed by the four $\mathrm{O}-\mathrm{CH}_{2}-\mathrm{PO}(\mathrm{Me})_{2}$ pendant arms.
\end{abstract}

(c) 2011 Elsevier B.V. All rights reserved.

\section{Introduction}

Actinide (An) coordination chemistry has been developed in somewhat limited way in consequence of their high radiotoxicity and the very small quantities available for some of the radio-isotopes [1]. Therefore, complexes with weakly $\alpha$-emitting, long half-life radio-elements such as uranium [2-6] and tetravalent thorium [7] have been the most studied while lanthanide ions ( $L n)$, in an indirect way, have afforded knowledge on the chemical behavior of trivalent actinides $[8,9]$. Thorium coordination chemistry is also well documented, both with respect to hydration and hydrolysis [10], complexes with oxygen- and nitrogen-donor ligands [7], macrocyclic complexes [11-13], and even quadruple-stranded helicates [14].

Lately, a large interest has developed for the interaction between $f$ elements and properly functionalized calixarenes, in the hope of designing adequate systems for their extraction and for

\footnotetext{
* Corresponding authors. Tel.: +52 53297200; fax: +52 53297301 (F. de M. Ramírez), tel.: +4121693 9821; fax: +41216939825 (J.-C.G. Bünzli).

E-mail addresses: flor.ramirez@inin.gob.mx (F. de María Ramírez), jean-claude. bunzli@epfl.ch (Jean-Claude G. Bünzli).
}

An/Ln separation. In particular, calixarenes fitted with pendant arms containing groups such as phosphoryl and/or amide have proved to display powerful extraction ability and large selectivity [15-26]. Effectiveness of these macrocycles in the treatment of radioactive wastes containing lanthanides, actinides, alkaline, and alkaline earths has been practically demonstrated [27]. Few calixarene complexes with thorium have been reported [11,21] while phosphorylated calixarenes have been successfully used for thorium extraction $[11,13,17,18,25,26]$.

Taking into account these considerations, we have been involved during the past years in the synthesis of two series of calix[ $n$ ]arenes $(n=4,6,8$, Scheme 1$)$ fitted with ether amide $[28,29]$ and phosphinoyl pendant arms on the narrow rim $[11,30-32]$. We have reported the structural and photophysical properties of their lanthanide complexes [28-32]. Recently, our work has been expanded to the study of actinide complexes formed with the phosphinoyl-derivatized calix[6]arene $\mathrm{B}_{6} \mathrm{bL}^{6}$, as well as to its extraction capability toward uranyl, thorium(IV), and representative trivalent rare earths ( $\mathrm{Y}, \mathrm{La}, \mathrm{Eu})$ [11]. The synergistic effect of the phosphinoyl-derivatized calix[4]arene $\mathrm{B}_{4} \mathrm{bL}^{4}$ in the extraction of lanthanides with a pyrazolone derivative has also been shortly reported by one of us [33]. Polystyrene microfibers 

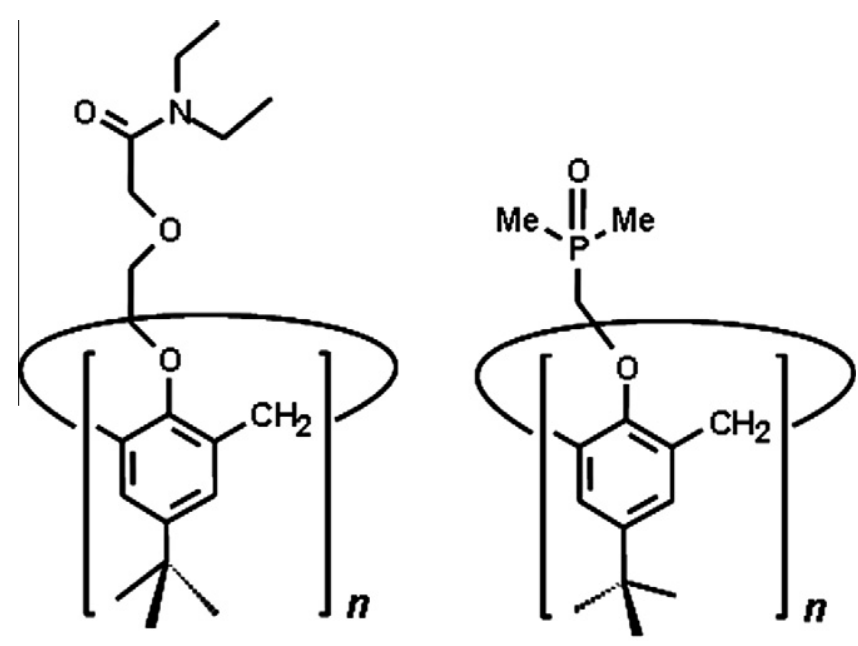

$$
\begin{array}{ll}
\mathrm{A}_{n} \mathrm{bL}^{n} & \mathrm{~B}_{n} \mathrm{bL}^{n} \\
n=4,6 & n=4,6,8
\end{array}
$$

Scheme 1. Calixarenes with ether amide and phosphinoyl pendant arms in the lower rims.

containing this lower-rim substituted calix[4]arene with phosphinoyl pendant arms were easily prepared in one-step procedure by electrospinning [34]. In the continuation of these studies, we report here on the coordination ability of $\mathrm{B}_{4} \mathrm{bL}^{4}$ toward thorium(IV) cations with a characterization of the resulting $1: 1$ and $1: 2$ complexes through several spectroscopic techniques, backed by model calculations as well as the X-ray structure of the 1:1 lanthanum complex. We also present the extraction properties of $\mathrm{B}_{4} \mathrm{bL}^{4}$ with respect to $f$-elements and Th/Ln separation.

\section{Experimental}

\subsection{Materials and methods}

$\mathrm{Th}\left(\mathrm{NO}_{3}\right)_{4} \cdot 5 \mathrm{H}_{2} \mathrm{O}$, ethanol and di-isopropyl ether were purchased from Merck. Nitric acid (purity 65.1\%, specific density 1.3989), formic acid (purity, 90\%), sodium formate and nitrate were from Baker. De-ionized water was kindly supplied by the staff of the Nuclear Reactor TRIGA Mark III from the Nuclear Center of Mexico. Anhydrous ( $<0.005 \%$ water) chloroform, acetonitrile, diethyl ether, as well as spectroscopic grade dichloromethane, acetonitrile, and Arsenazo III were purchased from Aldrich and used without further purification or dehydration. The lower-rim substituted p-tertbutylcalix[4]arene $\mathrm{B}_{4} \mathrm{bL}^{4}(5,11,17,23$-tetra-tert-butyl-25, 26, 27 , 28-tetrakis (dimethyl-phosphinoylmethoxy)calix[4]arene), was obtained as reported previously [30]. IR spectra were measured on a Perkin-Elmer series 1600 IR spectrometer. UV-Vis and diffuse reflectance spectra were recorded on a Perkin-Elmer Lambda 10 spectrophotometer using $1-\mathrm{cm}$ quartz cells and $\mathrm{MgO}$ pellets, respectively. Elemental analyses were performed on a PerkinElmer 2400 series II (UAM-I, México) instrument.

\subsection{Syntheses and characterization of the thorium complexes}

The hygroscopic $1: 1$ and 1:2 complexes were prepared according to the procedure reported recently for $\mathrm{B}_{6} \mathrm{bL}^{6}$ [11]. Yield: $65 \%$. Anal. Calc. for $\mathrm{Th}\left(\mathrm{B}_{4} \mathrm{bL}^{4}\right)\left(\mathrm{NO}_{3}\right)_{4} \cdot \mathrm{H}_{2} \mathrm{O}, \mathrm{C}_{56} \mathrm{H}_{86} \mathrm{~N}_{4} \mathrm{O}_{21} \mathrm{P}_{4} \mathrm{Th}$ (1): C, 44.63; H, 5.75; N, 3.72. Found: C, 44.70; $\mathrm{H}, 5.72 ; \mathrm{N}, 3.58 \%$. After heating the $\mathrm{KBr}$ disk at $95^{\circ} \mathrm{C}$ for $25 \mathrm{~h}$, IR $\left(\mathrm{cm}^{-1}\right): \mathrm{B}_{4} \mathrm{bL}^{4}: v\left(\mathrm{P}_{-} \mathrm{CH}_{3}\right)$, 1297; $v(\mathrm{P}=\mathrm{O}), 1196,1172 ; v\left(=\mathrm{C}-\mathrm{O}-\mathrm{CH}_{2^{-}}\right), 1018 ; v \mathrm{H}_{2} \mathrm{O}_{\text {lattice, }}$ 555,
522, 494, 356; (1): $v\left(\mathrm{P}-\mathrm{CH}_{3}\right), 1298 ; v(\mathrm{P}=\mathrm{O}), 1187 ; v\left(=\mathrm{C}-\mathrm{O}-\mathrm{CH}_{2}-\right)$ $1012 ; v \mathrm{NO}_{3 \text { ionic, }} 1384, v \mathrm{NO}_{3 \text { coord. }} 1547,1518,1490,761$ (monocoordinated), 1566, 1286 (bicoordinated); $v \mathrm{H}_{2} \mathrm{O}_{\text {lattice, }}, 550, v \mathrm{H}_{2} \mathrm{O}_{\text {coord, }}$, $508_{\text {strong }}, 365_{\mathrm{m} \text {-strong. }}$ Diffuse reflectance in $\mathrm{MgO}$ without drying the pellets $\left(\pi \rightarrow \pi^{*}\right.$ transitions, $\left.\mathrm{cm}^{-1}\right): \mathrm{B}_{4} \mathrm{bL}^{4}: \mathrm{P}=\mathrm{O}, 42020$ $(238 \mathrm{~nm}) ; \quad-\mathrm{C}=\mathrm{C}_{\text {phenyl }}, \quad 35335 \quad(283 \mathrm{~nm}) ; \quad$ (1) $\mathrm{P}=\mathrm{O}, \quad 45045$ $(222 \mathrm{~nm}) ;-\mathrm{C}=\mathrm{C}_{\text {phenyl, }} 33225(301 \mathrm{~nm})$. UV-Vis spectra in $\mathrm{CH}_{3} \mathrm{CN}$ : $\lambda_{\max } 275 \mathrm{~nm} ; \varepsilon\left(\mathrm{M}^{-1} \mathrm{~cm}^{-1}\right): \mathrm{B}_{4} \mathrm{bL}^{4}, 3780$; (1), 4408. Yield: 67\%. Anal. Calc. for $\mathrm{Th}\left(\mathrm{B}_{4} \mathrm{bL}^{4}\right)_{2}\left(\mathrm{NO}_{3}\right)_{4} \cdot 4 \mathrm{H}_{2} \mathrm{O}, \mathrm{C}_{112} \mathrm{H}_{176} \mathrm{~N}_{4} \mathrm{O}_{32} \mathrm{P}_{8} \mathrm{Th}(2)$ : C, 52.33; $\mathrm{H}, 6.90 ; \mathrm{N}, 2.18$. Found: C, 52.92; H, 7.17; N, 2.34\%. After heating the $\mathrm{KBr}$ disk at $95^{\circ} \mathrm{C}$ for $25 \mathrm{~h}, \mathrm{IR}\left(\mathrm{cm}^{-1}\right): v\left(\mathrm{P}-\mathrm{CH}_{3}\right), 1299 ; v(\mathrm{P}=\mathrm{O})$, 1195,$1173 ; v\left(=\mathrm{C}-\mathrm{OCH}_{2}-\right), 1021 ; v \mathrm{NO}_{3}$ ionic, $1384, v \mathrm{NO}_{3}$ coord., 1515,$768 ; v \mathrm{H}_{2} \mathrm{O}_{\text {lattice, }}$ 550, 493, 359; $v \mathrm{H}_{2} \mathrm{O}_{\text {coord. }}$ 509, 387. Diffuse reflectance in $\mathrm{MgO}$ without drying the pellets $\left(\pi \rightarrow \pi^{*}\right.$ transitions, $\left.\mathrm{cm}^{-1}\right), 35715 \mathrm{~cm}^{-1}(280 \mathrm{~nm})$. UV-Vis spectra in $\mathrm{CH}_{3} \mathrm{CN}$ : $\lambda_{\max }$ $275 \mathrm{~nm} ; \varepsilon\left(\mathrm{M}^{-1} \mathrm{~cm}^{-1}\right) 6215$.

\subsection{Extraction procedure}

The aqueous phases 1,2 and 3 of $\mathrm{Th}^{4+}$ and/or trivalent rare-earth nitrates ( $\mathrm{RE}=\mathrm{Y}, \mathrm{La}, \mathrm{Eu})$ were prepared as reported previously [11]. Organic phases of the calixarene were prepared in anhydrous chloroform. Organic phase $4: \mathrm{B}_{4} \mathrm{bL}^{4} 1.24 \times 10^{-4} \mathrm{M}$; organic phase 5: $\mathrm{B}_{4} \mathrm{bL}^{4} 3.27 \times 10^{-4} \mathrm{M}$ in order to maintain $1: 1$ and $1: 2$ metal-to-ligand ratio, respectively during the extraction process. The aqueous phase $\left(5 \mathrm{~cm}^{3}\right)$ containing the metal salt(s) was poured into a highquality glass vial fitted with a hermetic top; the corresponding organic $\mathrm{B}_{4} \mathrm{bL}^{4}$ phase $\left(5 \mathrm{~cm}^{3}\right)$ was then added. The vial was capped and shaken at a speed of $300 \mathrm{rpm}$ during $7 \mathrm{~h}$ at $291 \pm 2 \mathrm{~K}$. The vial was then kept still for $2 \mathrm{~h}$ to ensure optimum separation. When an emulsified phase formed between the organic and aqueous phases, the organic phase was slowly separated using a funnel; the combined aqueous and emulsified phases were filtered on a glass frit funnel $(4-5.5 \mu \mathrm{m})$ under vacuum (1.33 Pa). The added metal content of the aqueous and emulsified phases after filtration was always identical to that found in a portion of the aqueous phase before filtration. In general, the metal concentration was analyzed in each aqueous and organic phases before and after extraction by spectroscopic techniques, as described previously [11].

\subsection{Molecular modeling}

The structures were built and their minimum energies calculated using the CAChe WorkSystem Pro 5.02 program package for Windows ${ }^{\circledR}$ (Fujitsu Ltd., 2000-2001). Sequential application of Augmented MM3/CONFLEX procedures yielded the most stable conformers for compounds $\mathbf{1}$ and $\mathbf{2}$ and the free calixarene. The calixarene structure has also been calculated by MOPAC/PM5 and MOPAC/PM5/COSMO procedures. COSMO evaluates the solvent effect in the stabilization of a structure and therefore the resulting calixarene structure was the base for the simulation of the thorium complexes. The MOPAC procedure could not be applied to the thorium complex molecules because it lacks parameters for 5 -elements.

\subsection{X-ray crystal structure of $\left\{\left[\mathrm{LaB}_{4} b L^{4}\left(\mathrm{H}_{2} \mathrm{O}\right)_{5}\right] \mathrm{CH}_{3} \mathrm{CN}\right\} \cdot\left(\mathrm{ClO}_{4}\right)_{3}$}

The crystal data and structure refinement parameters are presented in Table 1 . Crystals were mounted in glass capillaries. Diffraction data were collected on a mar345 Imaging Plate Detector System. The cell was determined using 232 spots from the first image. Refinement of cell parameters, integration and scaling of data were performed with the program marHKL, release 1.9.1 [35]. No absorption correction was applied. The solution and refinement were performed by sHelx [36]. The structure was refined using full-matrix least-squares based on $F^{2}$ with all nonhydrogen atoms 
Table 1

Crystal data and structure refinement.

\begin{tabular}{|c|c|}
\hline Compound & {$\left[\mathrm{LaB}_{4} \mathrm{bL}^{4}\left(\mathrm{H}_{2} \mathrm{O}\right)_{5}\right] \mathrm{CH}_{3} \mathrm{CN} \cdot\left(\mathrm{ClO}_{4}\right)_{3}$} \\
\hline Formula unit & $\mathrm{C}_{58} \mathrm{H}_{97} \mathrm{Cl}_{3} \mathrm{LaNO}_{25} \mathrm{P}_{4}$ \\
\hline Molecular weight & 1577.51 \\
\hline Crystal system & tetragonal \\
\hline Space group & $P 4 / n($ ITC no. 85$)$ \\
\hline$a(\AA)$ & $14.080(2)$ \\
\hline$b(\AA)$ & $14.080(2)$ \\
\hline$c(\AA)$ & $23.794(5)$ \\
\hline$\alpha\left(^{\circ}\right)$ & 90.00 \\
\hline$\beta\left(^{\circ}\right)$ & 90.00 \\
\hline$\gamma\left({ }^{\circ}\right)$ & 90.00 \\
\hline$V\left(\AA^{3}\right)$ & $4717.1(13)$ \\
\hline$Z$ & 2 \\
\hline$\rho_{\text {calc }}\left(\mathrm{g} \mathrm{cm}^{-3}\right)$ & 1.111 \\
\hline$T(\mathrm{~K})$ & $140(2)$ \\
\hline$\mu\left(\mathrm{mm}^{-1}\right)$ & 0.663 \\
\hline$\lambda(\AA)$ & 0.71073 \\
\hline$F(000)$ & 1640 \\
\hline Total reflections & 5436 \\
\hline Observed reflections $[I>2 \sigma(I)]$ & 4452 \\
\hline Parameters refined & 288 \\
\hline$R_{1}[I>2 \sigma(I)]$ & 0.0745 \\
\hline$w R_{2}[I>2 \sigma(I)]$ & 0.2076 \\
\hline
\end{tabular}

anisotropically defined (except the $\mathrm{CH}_{3} \mathrm{CN}$ within the calixarene). Hydrogen atoms were placed in calculated positions by means of the "riding" model. Rotational disorder was evident in the case of the $t$-butyl group and $\mathrm{ClO}_{4}^{-}$; it was modeled by means of the split model and by the application of some reasonable restraints (SIMU, SADI, DFIX cards). The additional electronic density found outside the calixarene, representing highly disordered solvent $\left(\mathrm{CH}_{3} \mathrm{CN}\right.$ or $\mathrm{H}_{2} \mathrm{O}$ ), was treated by the SQUEEZE algorithm found in PLATON [37].

\section{Results and discussion}

\subsection{Isolation and characterization of the thorium complexes}

Reaction of $\mathrm{B}_{4} \mathrm{bL}^{4}$ with thorium nitrate in stoichiometric ratios $1: 1$ in ethanol and $1: 2$ in acetonitrile yielded the following white complexes: $\mathrm{Th}\left(\mathrm{NO}_{3}\right)_{4}\left(\mathrm{~B}_{4} \mathrm{bL}^{4}\right)_{n} \cdot x \mathrm{H}_{2} \mathrm{O}(n=1, x=1,1 ; n=2, x=4,2)$. The reaction yields for both thorium calixarene complexes were similar, pointing to the formation of species being essentially governed by the affinity of the phosphinoyl arms toward the metal ions. The $\mathrm{Th}\left(\mathrm{B}_{4} \mathrm{bL}^{4}\right)_{2}$ complex is more hydrated than the $1: 1 \mathrm{com}-$ pound, a fact which can be traced back to the large affinity of the phosphinoyl groups for water [11,30-32].

The vibrational spectra of the complexes reveal that one component of the $\mathrm{P}=\mathrm{O}$ vibrations of free $\mathrm{B}_{4} \mathrm{bL}^{4}$, at $1172 \mathrm{~cm}^{-1}$, disappears completely upon formation of the 1:1 complex (1) while the other component is slightly red shifted (Table 2). Bands attributable to coordinated (bidentate, monodentate) nitrate and water molecules are present in the spectrum as well as un-coordinated nitrate [38]. After drying, the spectrum does not change and two bands are seen at 508 and $365 \mathrm{~cm}^{-1}$ assigned to vibrations from coordinated water molecules; this implies that the water molecule is directly coordinated to the metal ion (Fig. S1, Supplementary data). As for the 1:1 complex, vibrations corresponding to coordinated nitrate and water molecules appear in the spectrum of the thorium 1:2 complex (2).

In the diffuse reflectance spectrum of the $1: 1$ complex the $\pi \rightarrow \pi^{*}(\mathrm{P}=\mathrm{O})$ transition is blue shifted by $3010 \mathrm{~cm}^{-1}$ with respect to the free ligand, while the $\pi \rightarrow \pi^{*}$ ( $C=C$-phenyl) transition is red shifted by $2115 \mathrm{~cm}^{-1}$. Once more the $\mathrm{P}=\mathrm{O}$-metal cation interaction is demonstrated and the involvement of the calixarene scaffold to the stability of this complex. The spectrum of the $1: 2$ complex was less informative.

\subsection{Solution study}

The UV-Vis spectra of $\mathrm{B}_{4} \mathrm{bL}^{4}$ and its complexes in acetonitrile display the main phenyl $\pi \rightarrow \pi^{*}$ ligand band in the range 275$279 \mathrm{~nm}$. It is slightly red shifted $(1-4 \mathrm{~nm})$ in the complexes which additionally display a shoulder on the low-energy side $(\approx 284 \mathrm{~nm})$. The molar absorption coefficient of the $1: 1$ complex is about $14 \%$ larger compared to the free ligand. In the corresponding complex with $\mathrm{B}_{6} \mathrm{bL}^{6}$ the increase in the molar absorption coefficient was about $20 \%$, indicating more influence of the metal center on the electronic structure of the larger calixarene, in line with its better suited conformation for interacting with actinides [11]. The molar absorption coefficient of the $1: 2$ complex is substantially smaller than two times the value for the free ligand, displaying $63 \%$ increase over the latter only. The increase is smaller than the one reported for the $1: 2$ complex with $\mathrm{B}_{6} \mathrm{bL}^{6}$ and $\mathrm{Th}^{4+}(+90 \%)$. Here again a similar explanation as above can be given. Contributions to the differences observed between the two complexes with $\mathrm{B}_{4} \mathrm{bL}^{4}$ on one hand, and between $\mathrm{B}_{4} \mathrm{bL}^{4}$ and $\mathrm{B}_{6} \mathrm{bL}^{6}$ complexes on the other hand, may come from differences in hydration and/or nitrate interaction.

\subsection{Molecular modeling}

In order to substantiate the experimental results described above, model calculations have been performed both in vacuum and in a polar solvent on the free calixarene and on the thorium complexes. Surprisingly, the predominant low-energy isomer calculated for $\mathrm{B}_{4} \mathrm{bL}^{4}$ was a 1,3 alternate conformer, even in water, while in less polar solvents such as $\mathrm{CHCl}_{3}$ and $\mathrm{CH}_{3} \mathrm{CN}$, NMR data

Table 2

Calculated structures for the free calixarene and their thorium complexes, and the most important spectroscopic data.

\begin{tabular}{|c|c|c|c|c|c|c|c|}
\hline \multirow[t]{3}{*}{ Compound } & \multirow[t]{3}{*}{$E\left(\mathrm{kcal} \mathrm{mol}^{-1}\right)^{\mathrm{a}}$} & \multirow[t]{3}{*}{ Proposed formula and geometry ${ }^{\mathrm{b}}$} & \multicolumn{4}{|c|}{ Vibrational frequencies $\left(\mathrm{cm}^{-1}\right)$} & \multirow[t]{3}{*}{$\varepsilon\left(\mathrm{M}^{-1} \mathrm{~cm}^{-1}\right)$} \\
\hline & & & \multirow[t]{2}{*}{$\mathrm{P}=\mathrm{O}$} & \multicolumn{2}{|l|}{$\mathrm{NO}_{3}^{-}$} & \multirow[t]{2}{*}{ Coordinated $\mathrm{H}_{2} \mathrm{O}$} & \\
\hline & & & & Monocoordinated & Bicoordinated & & \\
\hline $\mathrm{B}_{4} \mathrm{bL}^{4}$ & $37,37,-492,-516$ & 1,3 alternate cone conformer, $C_{4}$ & 1196,1172 & & & & 3780 \\
\hline 1 & 435,435 & $\begin{array}{l}{\left[\mathrm{Th}\left(\mathrm{B}_{4} \mathrm{bL}^{4}\right)\left(\mathrm{NO}_{3}\right)_{2}\left(\mathrm{H}_{2} \mathrm{O}\right)\right]^{2+}} \\
\mathrm{CN}=8 \text {; distorted square antiprism }\end{array}$ & 1187 & $\begin{array}{l}1518,1490 \\
1547,761\end{array}$ & 1286, 1566 & $508_{\mathrm{s}}, 365_{\mathrm{vw}}$ & 4408 \\
\hline \multirow[t]{2}{*}{2} & 639,625 & $\begin{array}{l}\text { Mean Th } \leftarrow \mathrm{O}=\mathrm{P}: 2.50(2) \AA \\
{\left[\mathrm{Th}\left(\mathrm{B}_{4} \mathrm{bL}^{4}\right)_{2}\left(\mathrm{NO}_{3}\right)\left(\mathrm{H}_{2} \mathrm{O}\right)_{2}\right]^{3+}} \\
\mathrm{CN}=9 \text {; distorted tricapped trigonal prism }\end{array}$ & $\begin{array}{l}1195 \\
1173\end{array}$ & 1515,768 & & $509_{\mathrm{m}}, 387_{\mathrm{m}}$ & 6215 \\
\hline & & Mean $\mathrm{Th} \leftarrow \mathrm{O}=\mathrm{P}: 2.52(2) \AA$ & & & & & \\
\hline
\end{tabular}

\footnotetext{
a In sequence: MM3, CONFLEX, MOPAC/PM5, and MOPAC/PM5/COSMO.

b From the optimum geometries found by MM3 and CONFLEX (CAChe WorkSystem Pro 5.02).
} 
are consistent with a cone conformation. Such conformation was also found for the acetonitrile adduct of this calixarene in the solid state by X-ray crystallography [30].

The structural versatility of actinide complexes in solution and solid arises from the lack of strong crystal field effects for the $5 f$ electronic configurations as well as from their large ionic radii. The predominant ionic character of the bonding leads to a wide variety of coordination numbers (CN) and symmetries. For thorium(IV) complexes, $\mathrm{CN}=8$ and 9 in square antiprismatic and trigonal prismatic geometries are the most common, although $\mathrm{CN}$ ranging from 6 to 12 have been found $[1,7,25]$. Thorium complexes with calixarenes are known, the most related with this work are complexes with CMPO-[18] and phosphine oxide-derivatized [11,17] calixarenes, whose stoichiometries suggest usually $\mathrm{CN}=8-9$.

\subsubsection{Th(IV) complexes}

The calculated coordination polyhedron of the most stable modeled structure of $\left[\mathrm{Th}\left(\mathrm{NO}_{3}\right)_{2}\left(\mathrm{~B}_{4} \mathrm{bL}^{4}\right)\left(\mathrm{H}_{2} \mathrm{O}\right)\right]^{2+}(\mathbf{1})$ is a distorted square antiprism $(\mathrm{CN}=8$; effective ionic radius $=1.19 \AA$ (Fig. 1) and a distorted tricapped trigonal prism $(\mathrm{CN}=9$; effective ionic radius $=1.23 \AA)$ for $\left[\mathrm{Th}\left(\mathrm{NO}_{3}\right)\left(\mathrm{B}_{4} \mathrm{bL}^{4}\right)_{2}\left(\mathrm{H}_{2} \mathrm{O}\right)_{2}\right]^{3+}(\mathbf{2})$. The 1,3 alternate conformation of the calculated calixarene is maintained in the complexes. In fact, electrostatic repulsion and van der Waals interaction energy terms from the ligands are detrimental to the calculated energy of the optimized molecular geometry (Table 1). However, bond lengths and angles are in the usual range for Th-O coordination $[7,11]$. The $\mathrm{Th} \leftarrow \mathrm{OP}$ average bond lengths are $2.505 \pm 0.025$ and $2.521 \pm 0.085 \AA$ for $\mathbf{1}$ and 2, respectively (Supplementary data, Table S1). A model of $\mathbf{2}$ with two calixarenes completely coordinated to Th(IV) does not yield the most stable structure $(\mathrm{CN}=8)$; however, three $\mathrm{OP}$ arms per calixarene, one monodentate nitrate and two water molecules coordinated to $\mathrm{Th}(\mathrm{IV})$, yield the most stable structure given above. This is in agreement with the experimental results. For instance, the infrared spectrum of 2 reveals that not all the OP arms of the calixarenes are coordinated to the cation and bands corresponding to coordi- nated water molecule and monocoordinate-nitrate were observed (see Section 2). The overall shape of the OP bands was very similar to that of $\mathrm{Th}\left(\mathrm{B}_{6} \mathrm{bL}^{6}\right)_{2}$ [11], for which we proposed the two calixarenes to be partially coordinated to thorium. However, the minimum energies resulting from the semiempirical calculations of the thorium $\mathrm{B}_{4} \mathrm{bL}^{4}$ complexes suggest their lower stability with respect to those formed with $\mathrm{B}_{6} \mathrm{bL}^{6}$ probably due to the smaller size of $\mathrm{B}_{4} \mathrm{bL}^{4}$, an effect which is not compensated by its rigidity.

\subsection{Liquid-liquid extraction of f-elements}

The extraction ability of $\mathrm{B}_{4} \mathrm{bL}^{4}$ toward Th(IV), Y(III), La(III), and $\mathrm{Eu}(\mathrm{III})$ ions was tested. The study was performed using three different aqueous nitric phases (aqueous phases 1,2 and 3) and two different calixarene concentrations in chloroform corresponding to metal:ligand ratios of $\approx 1$ (organic phase 4 ) and $\approx 2.5$ (phase 5 ). Results are collected in Table 3 .

Generally speaking, actinide cations are much better extracted than rare earths, which is encouraging in the perspective of $\mathrm{An} /$ Ln separation since in some cases theoretical separation factors are very large. Increasing the concentration of the calixarene by a factor 2.5 in going from organic phase 4 to phase 5 leads to a concomitant increase in the extraction of the thorium cations (average increase is 2.3-fold), in line with the formation of 1:2 complex demonstrated in the above description. However, the extraction efficiency of $\mathrm{Th}^{4+}$ also depends on the aqueous phase. Increasing the concentration of nitric acid in the aqueous phase from 1 to $3 \mathrm{M}$ is quite detrimental to thorium extraction about 25-30\%. However, boosting sodium nitrate concentration from 0.5 to 3.5 M results in a much better extraction of thorium by a factor $\approx 2$. It has been recently demonstrated that the salting-out effect plays an important role in $\mathrm{Th}^{4+} / \mathrm{La}^{3+}$ separation with calix[6]arene $\mathrm{B}_{6} \mathrm{bL}^{6}[11]$. We find a similar behavior with $\mathrm{B}_{4} \mathrm{bL}^{4}$ since the increase in nitrate concentration gives rise to a remarkable improvement in $\mathrm{La}^{3+}$ extraction, by a factor $\approx 10$. Consequently, the extraction selectivity (Th/La) for the more concentrated organic phase 5 goes down
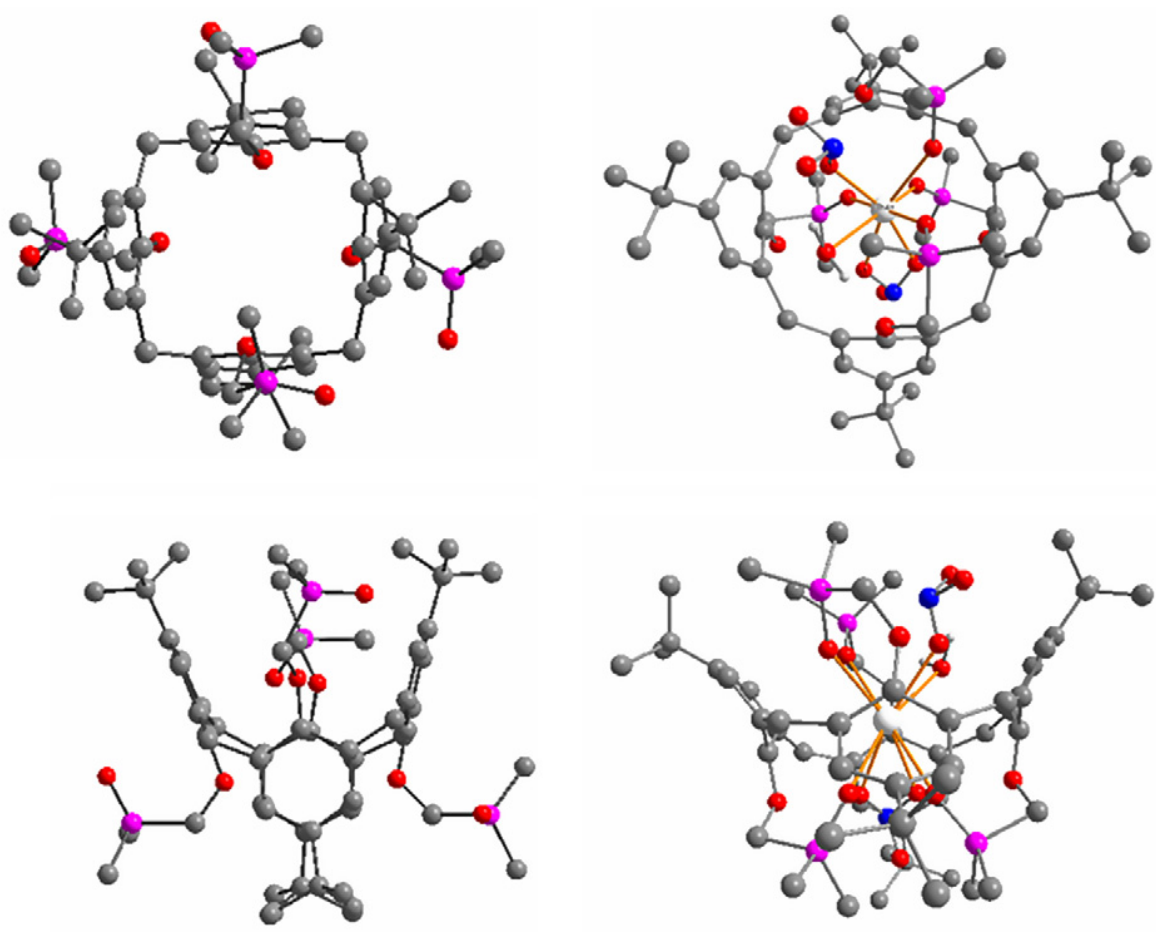

Fig. 1. On the right side, two views of the modeled $\left[\mathrm{Th}\left(\mathrm{NO}_{3}\right)_{2} \mathrm{~B}_{4} \mathrm{bL}^{4}\left(\mathrm{H}_{2} \mathrm{O}\right)\right]^{2+}$ by Augmented MM3/CONFLEX calculations, and on the left side those of the free calixarene $\mathrm{B}_{4} \mathrm{bL}{ }^{4}$ by MOPAC/PM5/COSMO calculations. Hydrogen atoms have been removed for clarity. 
Table 3

Percentages of recovered cations after liquid-liquid extraction of thorium and rare earth nitrates at $18 \pm 2{ }^{\circ} \mathrm{C}_{\text {by }} \mathrm{B}_{4} \mathrm{bL}^{4}$ in chloroform $(7 \mathrm{~h}$ shaking).

\begin{tabular}{|c|c|c|c|c|c|c|c|c|c|}
\hline \multirow[t]{3}{*}{ Cation } & \multirow{3}{*}{$\begin{array}{l}\text { Aqueous phase } \\
{\left[\mathrm{M}\left(\mathrm{NO}_{3}\right)_{n}\right] / 10^{-4} \mathrm{M}}\end{array}$} & \multicolumn{2}{|c|}{ Organic phase, $\left[\mathrm{B}_{4} \mathrm{bL}^{4}\right] / 10^{-4} \mathrm{M}$} & \multicolumn{6}{|c|}{ Extraction selectivity $^{\mathrm{a}}$} \\
\hline & & & & \multicolumn{2}{|c|}{ Th/La } & \multicolumn{2}{|c|}{ Th/Eu } & \multicolumn{2}{|c|}{$\mathrm{Th} / \mathrm{Y}$} \\
\hline & & $1.27(4)$ & $3.17(5)$ & $(4)$ & $(5)$ & $(4)$ & $(5)$ & $(4)$ & $(5)$ \\
\hline \multicolumn{4}{|c|}{$1 \mathrm{M} \mathrm{HNO}_{3}-0.5 \mathrm{M} \mathrm{NaNO}_{3}(1)$} & 7 & 11 & 2 & 3 & 3 & 6 \\
\hline $\mathrm{Th}^{4+}$ & 1.30 & $21.2 \pm 0.4$ & $53.8 \pm 0.8$ & & & & & & \\
\hline $\mathrm{La}^{3+}$ & 1.29 & $3.0 \pm 1.0$ & $5.0 \pm 1.0$ & & & & & & \\
\hline $\mathrm{Eu}^{3+}$ & 1.08 & $14.0 \pm 1.1$ & $16.0 \pm 1.2$ & & & & & & \\
\hline $\mathrm{Y}^{3+}$ & 1.15 & $7.0 \pm 0.1$ & $9.0 \pm 0.2$ & & & & & & \\
\hline \multicolumn{4}{|c|}{$1 \mathrm{M} \mathrm{HNO}_{3}-3.5 \mathrm{M} \mathrm{NaNO}_{3}(2)$} & 1 & 2 & & & 10 & 3 \\
\hline $\mathrm{Th}^{4+}$ & 1.17 & $55.8 \pm 1.0$ & $79.0 \pm 1.0$ & & & & & & \\
\hline $\mathrm{La}^{3+}$ & 1.11 & $38.7 \pm 1.1$ & $43.8 \pm 1.1$ & & & & & & \\
\hline $\mathrm{Eu}^{3+}$ & 1.19 & no extraction & no extraction & & & & & & \\
\hline $\mathrm{Y}^{3+}$ & 1.19 & $5.60 \pm 0.03$ & $23.5 \pm 1.1$ & & & & & & \\
\hline \multicolumn{4}{|c|}{$3 \mathrm{M} \mathrm{HNO}_{3}-0.5 \mathrm{M} \mathrm{NaNO}_{3}(3)$} & & & 80 & 3 & & \\
\hline $\mathrm{Th}^{4+}$ & 1.09 & $16.0 \pm 0.4$ & $38.3 \pm 0.8$ & & & & & & \\
\hline $\mathrm{La}^{3+}$ & 1.16 & no extraction & no extraction & & & & & & \\
\hline $\mathrm{Eu}^{3+}$ & 1.28 & $0.20 \pm 0.03$ & $13.0 \pm 1.0$ & & & & & & \\
\hline $\mathrm{Y}^{3+}$ & 1.24 & no extraction & no extraction & & & & & & \\
\hline
\end{tabular}

a Extraction selectivity is not given when the rare earth is not extracted.

9-fold for thorium under these experimental conditions, although Th(IV) is $80 \%$ extracted. For rare-earth ions, the extraction percentages are usually small or even in several cases no extraction is detectable. In particular, the behavior of $\mathrm{B}_{4} \mathrm{bL}^{4}$ as extractant for rare earths is similar to that found for the $p$-tert-butylcalix[4]arene derivative containing diphenyl-phosphinoyl [15] or other phosphoryl groups $[17,26]$.

\subsection{Stoichiometric correlation of extraction-complexation data}

It has been reported that extraction of thorium in dichloromethane containing $p$-tert-butylcalix[4-8]arene diphenylphosphine oxides attached to the lower rim results in the co-extraction of complexes with different stoichiometries; indeed, the slopes of the $\log \mathrm{D}$ versus $\log [\mathrm{L}]$ graphs are between 1.8 and 2.6 and coextraction of nitric acid or activity coefficients could not be ruled out [17]. For europium, the slopes are between 2.0 and 2.5. Ln complexation studies with these ligands revealed 1:1 species for $\mathrm{Pr}^{3+}$, $\mathrm{Eu}^{3+}$ and $\mathrm{Er}^{3+}$ [17]. Recently, a 1:1 stoichiometry was reported for the europium species extracted from acidic media into $m$-nitrobenzotrifluoride with $p$-tert-butylcalix[5]arene di-butylphosphine oxide [26]. Complexation studies with this ligand in acetonitrile revealed $1: 1$ stoichiometry for europium while with the $p$-tert-butylcalix[4]arene di-butylphosphine oxide ligand 1:1 and 1:2 Eu:ligand ratios were found in methanol. The stoichiometry of thorium and europium species extracted from acidic-salty media with $\mathrm{B}_{6} \mathrm{bL}^{6}$ into chloroform was $1: 1$ [11]. In the present work with $\mathrm{B}_{4} \mathrm{bL}^{4}$, no stoichiometry could be established for the Th(IV) and Eu(III) species: distribution ratios could not be estimated for calixarene concentrations larger than $4 \times 10^{-4} \mathrm{M}$, the emulsified phase between the aqueous and organic phases starting to be problematic (Table 3, aqueous phase 2).

Complexation studies of lanthanides with $\mathrm{B}_{4} \mathrm{bL}^{4}[30]$ and $\mathrm{B}_{6} \mathrm{bL}^{6}$ $[11,31]$ in acetonitrile revealed two predominant species with $1: 1$ and 1:2 stoichiometries. The corresponding isolated complexes with thorium and europium were obtained with reaction yields between $50 \%$ and $65 \%[11,30,31]$ very close to those found for the thorium complexes reported in the present work (65-67\%). We note that lanthanum is better extracted than europium with aqueous phase 2 (Section 3.6) and the reaction yields of its complexes with $\mathrm{B}_{4} \mathrm{bL}^{4}$ was $80(1: 1)$ and $66(1: 2) \%$, respectively [30]. This encouraged us to try to isolate single crystals suitable for X-ray analysis. Out of all experiments carried out, only the 1:1 complex of $\mathrm{B}_{4} \mathrm{bL}^{4}$ with lanthanum could be crystallized, the structure of which is described in the following section.

\subsection{Crystal structure of $\left\{\left[\mathrm{LaB}_{4} b L^{4}\left(\mathrm{H}_{2} \mathrm{O}\right)_{5}\right] \mathrm{CH}_{3} \mathrm{CN}\right\} \cdot\left(\mathrm{ClO}_{4}\right)_{3}$}

Single tetragonal crystals with composition $\left[\mathrm{LaB}_{4} \mathrm{bL}^{4}\left(\mathrm{H}_{2} \mathrm{O}\right)_{5}\right.$ ] $\mathrm{CH}_{3} \mathrm{CN}$. $\left(\mathrm{ClO}_{4}\right)_{3}$ and suitable for X-ray crystallography could be obtained by slow diffusion of diisopropyl ether into a $1: 2\left(\mathrm{La}: \mathrm{B}_{4} \mathrm{bL}^{4}\right)$ solution in non-anhydrous acetonitrile. The crystals belong to the $P 4 / n$ crystallographic space group and the corresponding molecular structure is displayed on Fig. 2 while distances and angles relevant to the coordination polyhedron are listed in Table 4 . The La ${ }^{\text {III }}$ cation lies on the $\mathrm{C}_{4}$ axis and is 9 -coordinated by the four $\mathrm{O}(\mathrm{P})$ atoms and five $\mathrm{O}$ atoms from water molecules. It sits on top of the macrocycle and therefore is not encapsulated into its cavity. Four water molecules are bound on the upper side while the fifth one (lying on the crystallographic 4-fold axis) is located in the middle of the void formed by the four $\mathrm{O}-\mathrm{CH}_{2}-\mathrm{PO}(\mathrm{Me})_{2}$ pendant arms. It is most probably held in this position by a remarkable network of symmetrical hydrogen bonds since $\mathrm{O}(1) \ldots \mathrm{O}(3)$ contacts are 2.886(3) $\AA$ ( $\mathrm{H}$ atoms could not be located). The coordination polyhedron is a monocapped square antiprism with $C_{4 v}$ symmetry, the four $\mathrm{O}(4)$ and $\mathrm{O}(2)$ atoms defining the upper and lower planes, respectively while their centroid, the La and the $\mathrm{O}(3)$ atoms are perfectly aligned. The average La-O bond length is equal to 2.549 (3) $\AA$, with significant differences among them. The La-O(2) distance [2.464(3) $\AA$ ] is standard for 9coordinated $\mathrm{La}^{\mathrm{III}}$, but $\mathrm{La}-\mathrm{O}(4)$ is 0.177 A longer. This may be traced back to weak interactions with perchlorates: four anions (each having occupancy 0.75 ) are located on top of and in between the four $\mathrm{H}_{2} \mathrm{O}(4)$ molecules with one oxygen atom of each at 2.86(1) A contact distance from $\mathrm{O}(4)$. The $\mathrm{La}-\mathrm{O}(3)$ distance is $0.057 \AA$ longer than $\mathrm{La}-\mathrm{O}(2)$ again in line with the water molecule implied in $\mathrm{H}$-bonding. The calixarene adopts its classical cone conformation and an acetonitrile molecule, lying on the 4 -fold axis, is inserted into the lower rim. This structure corresponds to one of the two structures evidenced in acetonitrile solution by NMR spectroscopy [35]. The structure of a 1:2 lanthanum complex with diethoxyphosphorylp-tert-calix[4]arene has been reported [39]. The two calixarenes adopt a cone conformation and a pseudo $\mathrm{C}_{4}$ axis goes through the lanthanum atom and the centers of the two cones. The La-O distances lie in a narrow range (2.42-2.55 $\AA$ ) with a mean value of $2.49 \AA$, quite comparable the $\mathrm{La}-\mathrm{O}(2)$ bond length reported in Table 4. 


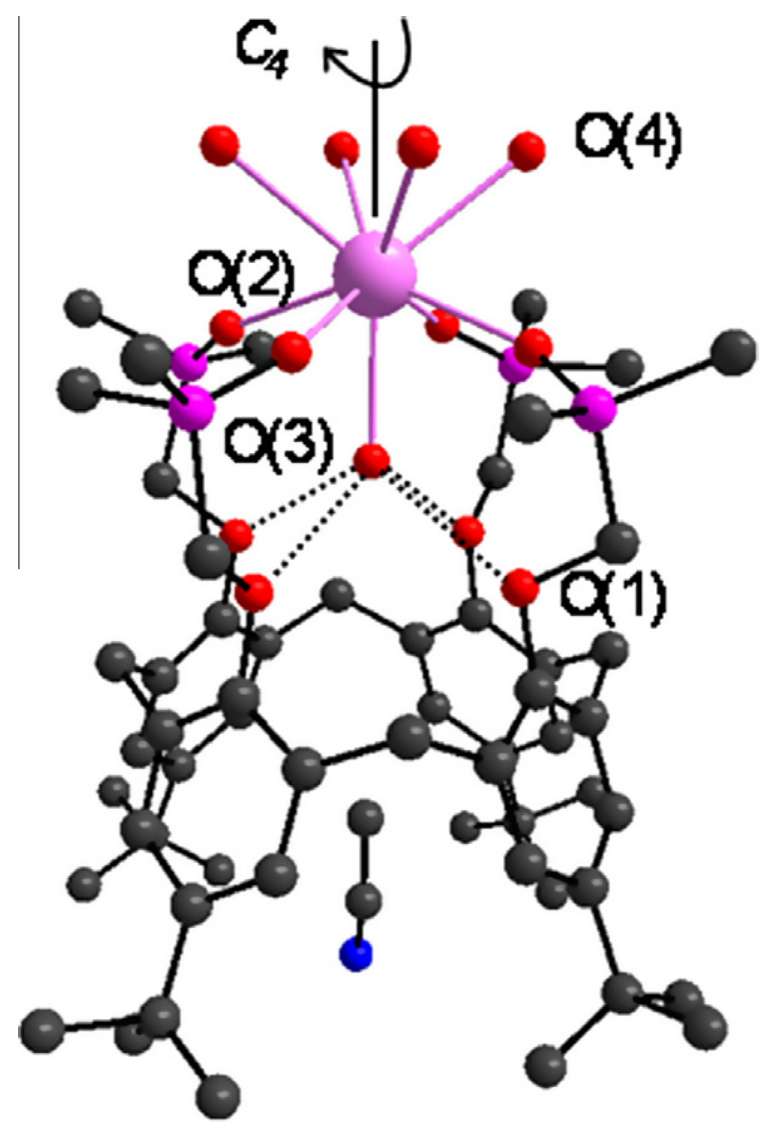

Fig. 2. Molecular structure of tetragonal $\left\{\left[\mathrm{LaB}_{4} \mathrm{bL}^{4}\left(\mathrm{H}_{2} \mathrm{O}\right)_{5}\right]^{3+} \cdot \mathrm{CH}_{3} \mathrm{CN}\right\}$ cation with Oatom numbering scheme; for the sake of clarity hydrogen atoms have been removed.

Table 4

Distances and angles pertaining to the coordination polyhedron in $\left[\mathrm{LaB}_{4} \mathrm{bL}^{4}\left(\mathrm{H}_{2} \mathrm{O}\right)_{5}\right]^{3+}$. refer to Fig. 2 for atom labeling.

\begin{tabular}{|c|c|c|c|c|c|}
\hline \multicolumn{2}{|c|}{ Distances $(\AA)$} & \multicolumn{4}{|l|}{ Angles $\left({ }^{\circ}\right)$} \\
\hline $\mathrm{La}-\mathrm{O}(2)$ & $2.464(3)$ & $\mathrm{O}(2)-\mathrm{La}-\mathrm{O}(2)$ & $83.33(4)$ & $\mathrm{O}(3)-\mathrm{La}-\mathrm{O}(4)$ & $127.62(7)$ \\
\hline $\mathrm{La}-\mathrm{O}(3)$ & $2.521(5)$ & $\mathrm{O}(2)-\mathrm{La}-\mathrm{O}(3)$ & $70.07(6)$ & $\mathrm{O}(4)-\mathrm{La}-\mathrm{O}(2)$ & $68.66(9)$ \\
\hline $\mathrm{La}-\mathrm{O}(4)$ & $2.641(3)$ & $\mathrm{O}(2)-\mathrm{La}-\mathrm{O}(4)$ & $74.41(9)$ & $\mathrm{O}(4)-\mathrm{La}-\mathrm{O}(4)$ & $68.12(8)$ \\
\hline
\end{tabular}

\section{Conclusions}

The tetra-phosphinoylated $p$-tert-butylcalix[4]arene forms stable thorium complexes with 1:1 and 1:2 stoichiometries in organic media. A combination of several experimental analytical techniques and theoretical modeling leads to the conclusion that coordination numbers are most probably 8-9 in these edifices. The $\mathrm{B}_{4} \mathrm{bL}^{4}$ calixarene is a reasonably good extractant for thorium but a poor one for rare earths. The extraction behavior and separation ability is much dependent on the initial conditions, $\mathrm{pH}$ and nitrate concentration, so that modulation of the extraction process is easy. Further study on these systems will be focused on more lipophilic macrocyclic receptors in which the wider rim of the calixarene is decorated with octyl substituents.

\section{Acknowledgments}

This work was supported through Grants from CONACYT (México), Project No. 36689-E and the Swiss National Science Foundation Project SCOPES 2000-2003 No. 7BUPJ062293.

\section{Appendix A. Supplementary material}

CCDC 812313 contains the supplementary crystallographic data for $\left\{\left[\mathrm{LaB}_{4} \mathrm{bL}^{4}\left(\mathrm{H}_{2} \mathrm{O}\right)_{5}\right] \mathrm{CH}_{3} \mathrm{CN}\right\} \cdot\left(\mathrm{ClO}_{4}\right)_{3}$. These data can be obtained free of charge from The Cambridge Crystallographic Data Centre via www.ccdc.cam.ac.uk/data_request/cif. Supplementary data associated with this article can be found, in the online version, at doi:10.1016/j.ica.2011.08.049.

\section{References}

[1] S. Cotton, Lanthanide and Actinide Chemistry, John Wiley and Sons Ltd., Chichester, 2006

[2] S. Mishra, Coord. Chem. Rev. 252 (2008) 1996.

[3] J.L. Sessler, P.J. Melfi, G.D. Pantos, Coord. Chem. Rev. 250 (2006) 816.

[4] A.D. Sutton, G.H. John, M.J. Sarsfield, J.C. Renshaw, L. May, L.R. Martin, A.J Selvage, D. Collison, M. Helliwell, Inorg. Chem. 43 (2004) 5480.

[5] I. Billard, in: K.A. Gschneidner Jr., J.-C.G. Bünzli, V.K. Pecharsky (Eds.), Handbook on the Physics and Chemistry and Rare Earths, vol. 33, Elsevier Science, B.V., Amsterdam, 2003, p. 465.

[6] P. Thuery, M. Nierlich, B. Masci, Z. Asfari, J. Vicens, J. Chem. Soc., Dalton Trans. (1999) 3151.

[7] R.K. Agarwal, H. Agarwal, K. Arora, Rev. Inorg. Chem. 20 (2000) 1.

[8] G.R. Choppin, E.N. Rizkalla, in: H. Gunzler, L. Eyring, G.R. Choppin, G.H. Lander (Eds.), Handbook on the Physics and Chemistry of Rare Earths, vol. 18, Elsevier Science Publ., B.V., Amsterdam, 1994, p. 559.

[9] N.M. Edelstein, J. Alloys Compd. 223 (1995) 197.

[10] N. Torapava, I. Persson, L. Eriksson, D. Lundberg, Inorg. Chem. 48 (2009) 11712.

[11] F.d.M. Ramirez, S. Varbanov, J.P. Padilla, J.-C.G. Bünzli, J. Phys. Chem. B 112 (2008) 10976.

[12] M.P. Placidi, L.S. Natrajan, D. Sykes, A.M. Kenwright, S. Faulkner, Helv. Chim. Acta 92 (2009) 2427.

[13] G.G. Talanova, Ind. Eng. Chem. Res. 39 (2000) 3550.

[14] J.D. Xu, K.N. Raymond, Angew. Chem., Int. Ed. 45 (2006) 6480.

[15] M.R. Yaftian, M. Burgard, D. Matt, C.B. Dieleman, F. Rastegar, Solv. Extr. Ion Exch. 15 (1997) 975

[16] L. Troxler, M. Baaden, V. Böhmer, G. Wipff, Supramol. Chem. 12 (2000) 27.

[17] F. Arnaud-Neu, S. Barboso, D. Byrne, L.J. Charbonnière, M.J. Schwing-Weill, G. Ulrich, in: G.J. Lumetta, R.D. Rogers, A.S. Galopan (Eds.), Calixarenes for Separations, Symposium Series No. 757, Am. Chem. Soc. Washington, DC 2000, p. 150

[18] B. Lambert, V. Jacques, A. Shivanyuk, S.E. Matthews, A. Tunayar, M. Baaden, G. Wipff, V. Böhmer, J.F. Desreux, Inorg. Chem. 39 (2000) 2033

[19] Z. Asfari, V. Böhmer, J. M. Harrowfield, J. Vicens (Eds.), Calixarenes 2001 Kluwer Academic Publishers, Dordrecht, 2001.

[20] W. Sliwa, Croat. Chim. Acta 75 (2002) 131.

[21] W. Sliwa, T. Girek, J. Incl. Phenom. Macrocycl. Chem. 66 (2010) 15

[22] B. Mokhtari, K. Pourabdollah, N. Dallali,J. Radioanal. Nucl. Chem. 287 (2011) 921.

[23] B. Mokhtari, K. Pourabdollah, N. Dallali, J. Incl. Phenom. Macrocycl. Chem. 69 (2011) 1 .

[24] J.F. Dozol, R. Ludwig, in: A.K. Serigupta, B.A. Moyer, Series (Eds.), Ion Exchange and Solvent Extraction, vol. 19, CRC Press, Taylor and Francis Group, LLC, USA, 2010, p. 195.

[25] S.D. Alexandratos, S. Natesan, Ind. Eng. Chem. Res. 39 (2000) 3998

[26] M. Karavan, F. Arnaud-Neu, V. Hubscher-Bruder, I. Smirnov, V. Kalchenko, J. Incl. Phenom. Macrocycl. Chem. 66 (2010) 113.

[27] M. Galletta, L. Baldini, F. Sansone, F. Ugozzoli, R. Ungaro, A. Casnati, M. Mariani, Dalton Trans. 39 (2010) 2546

[28] F.d.M. Ramirez, L.J. Charbonnière, G. Muller, R. Scopelliti, J.-C.G. Bünzli, J. Chem. Soc., Dalton Trans. (2001) 3205.

[29] F.d.M. Ramirez, L.J. Charbonnière, G. Muller, J.-C.G. Bünzli, Eur. J. Inorg. Chem. (2004) 2348

[30] L. Le Saulnier, S. Varbanov, R. Scopelliti, M. Elhabiri, J.-C.G. Bünzli, J. Chem. Soc., Dalton Trans. (1999) 3919.

[31] F.d.M. Ramirez, S. Varbanov, C. Cécile, G. Muller, N. Fatin-Rouge, R. Scopelliti, J.-C.G. Bünzli, J. Chem. Soc., Dalton Trans. (2002) 4505.

[32] L.N. Puntus, A.-S. Chauvin, S. Varbanov, J.-C.G. Bünzli, Eur. J. Inorg. Chem. (2007) 2315.

[33] M. Atanassova, V. Lachkova, N. Vassilev, S. Varbanov, I. Dukov, J. Incl. Phenom. Macrocycl. Chem. 58 (2007) 173.

[34] M. Ignatova, N. Manolova, V. Lachkova, S. Varbanov, I. Rashkov, Macromol Rapid Commun. 29 (2008) 1871

[35] Z. Otwinowski, W. Minor, in: C.W. Carter Jr., R.M. Sweet (Eds.) Macromolecular Crystallography, Part A, vol. 276, Academic Press, New York, 1997, p. 307.

[36] G.M. Sheldrick, Acta Crystallogr., Sect. A 64 (2008) 112.

[37] A.L. Spek, PLATON, A Multipurpose Crystallographic Tool, Utrecht University, Utrecht, The Netherlands, 2010.

[38] K. Nakamoto, Infrared and Raman Spectra of Inorganic and Coordination Compounds. Part A. Theory and Applications in Inorganic Chemistry, John Wiley Interscience Publ., New York, 1997.

[39] J.M. Harrowfield, M. Mocerino, B.J. Peachey, B.W. Skelton, A.H. White, Dalton Trans. (1996) 1687. 